\title{
ABOUT THE CONTRIBUTORS
}

Michael Keating is Professor of Politics at the University of Aberdeen and the University of Edinburgh.

David McCrone is Professor Emeritus of Sociology at the University of Edinburgh.

Colin Crouch is Professor Emeritus of the University of Warwick, and external scientific member of the Max Planck Institute for the Study of Societies, Cologne.

David Heald is Professor of Accountancy at the University of Aberdeen Business School.

Desmond Hickie is Professor Emeritus at the University of Chester.

Ulrich Hilpert is Chair of Comparative Government, Friedrich Schiller University Jena.

Yves Mény is Emeritus President, European University Institute.

Susi Meret is Assistant Professor at the Department of Culture and Global Studies, Aalborg University, Denmark.

Henry Milner is senior research fellow at the Chair in Electoral Studies, Department of Political Science, Université de Montréal.

Martin Rhodes is Professor of Comparative Political Economy and Associate Dean at the Josef Korbel School of International Studies, University of Denver, Colorado.

Bo Rothstein holds the August Röhss Chair in Political Science at the University of Gothenburg. 
viii ]

Donald Sassoon is Professor of Comparative European History, Queen Mary, University of London.

Birte Siim is Professor in Gender Research in Social Science at Aalborg University, Denmark.

Sven Steinmo is a Professor of Political Science at the University of Colorado, Boulder, and Chair in Political Economy and Public Policy at the European University Institute, Florence.

Milada Anna Vachudova is Associate Professor of Political Science at the University of North Carolina at Chapel Hill.

Neil Walker is Regius Professor of Public Law and the Law of Nature and Nations at the University of Edinburgh. 